\title{
The importance of hourly nutrient concentration variability in terms of assessment of the sur- face water state in Słupia Pilot River
}

\author{
Paweł Wilk, Joanna Gębala, Paulina Orlińska-Woźniak, Mieczysław Ostojski \\ Institute of Meteorology and Water management - National Research Institute, Podleśna 61, 01-673 Warsaw, Poland, \\ e-mail:pawel.wilk@imgw.pl,joanna.gebala@imgw.pl,paulina.wozniak@imgw.pl,mieczyslaw.ostojski@imgw.pl
}

\begin{abstract}
Water eutrophication still causes many environmental and social problems, and so better quantification of the amount of nutrient loads discharged into surface waters is required. The basis for eutrophication analysis is data gathered in the frame of State Environmental Monitoring (SEM). In Poland, these measurements are carried out at the frequency of 6-12 times per year and serve as the basis for calculating the amount of nutrient input discharged to the sea.

This article presents the results of the analysis of the representativeness of one measurement make two-hourly per day of the variability of total nutrient concentrations. For this purpose three cycles of field studies were carried out in accordance with plant growing season. The measurements were taken in November 2013, February 2014, and June 2014 in the Stupia River, at the site where it flows through the village of Charnowo (river profile). The analysis showed a significant change in the amount of total nutrient concentration during the day (up to $60 \%$ for total nitrogen and total phosphorus). This trend was maintained regardless of the stage of plant growth.

Therefore, both the date for water sample collection and the time the measurement was taken become important for the subsequent evaluation of nutrient loads discharged into the sea. It is reasonable to assess the level of nutrient loads discharged into the sea not on the basis of a single measurement but based on the continuous registration of nutrients - this allows us to assign a daily average. It is also important from the point of view of the calibration of mathematical models, which are now an essential tool for analysing and forecasting environmental changes, and for which access to detailed data is very important.
\end{abstract}

Keywords: nutrients, measurement uncertainty, total nitrogen, total phosphorus, dispersion

Submitted 13 May 2015, revised 4 August 2015, accepted 18 March 2016

\section{Introduction}

The classification of surface water status is carried out in accordance with a regulation (Dz. U. z 2011 r. Nr 257, poz. 1545). This regulation specifies, inter alia, a method for assessing the results of studies of water quality indicators, the assessment of surface water bodies, the frequency of the classification of individual components, as well as the classification of ecological water status and the potential and chemical status of surface waters. In order to reach a good water status by 2015 (Directive 2000/60/EC; Ostojski 2008) Poland is now taking actions to reduce nutrient discharges (Gębala et al. 2013). Little is known about how small estuaries with short residence times respond to increased nutrient loading - specifically, how such systems respond to runoff events and how physical and biological processes control nutrient concentrations.

Despite the fact that the reduction of the nutrient input discharged from Polish rivers into the Baltic waters has been significant, nutrient levels are still too high.

The water quality of rivers is a highly complex param- eter, both spatially and temporally. It depends, inter alia, on meteorological and hydrological conditions. A characteristic feature of rivers is that the flow of matter takes place in one direction, "down the system" (Caffrey et al. 2007). Variability in a river's nutrient concentrations probably arises due to the variability in the strength of its sources, in hydrological transport processes and, conceivably, because of a river's biological activity. However, in order to reveal the existence of such associations it is imperative that the periodicity of sampling is appropriately matched with the natural scales of variance of the physical, chemical and biological processes involved. Water flow also has a significant impact on the variability of nutrients in rivers. However, this article focuses only on the values of concentrations of total nitrogen and total phosphorus and, therefore, flow has not been taken into consideration. The calculation of the quantity of nutrients is based on data obtained from monitoring measurements carried out by the Polish State Environmental Monitoring (SEM) (Directive 2000/60/EC). The measurements are performed at the frequency of 6-12 times per year for both total nitrogen and 
total phosphorus (Dz. U. z 2011 r. Nr 258, poz. 1550). This means that the measurement is as frequent as once or twice a month, and the results are considered to be representative for a particular day or month. However, the evaluation of water quality by means of a single instantaneous measurement is burdened with errors inherent in uncontrolled environmental variability. This means that the result of the single instantaneous measurement deviates from the real average daily value and is not typical for a particular day or month. This lack of representativeness might be vital in assessing the quantity of total nitrogen and total phosphorus released into surface waters. In order to analyse the representativeness of a single instantaneous measurement for specified quantities of total nutrient concentrations, field studies were conducted on the Słupia River. This allowed for the estimation of the hourly variability of total nitrogen and total phosphorus concentrations in waters flowing into the Baltic Sea (Ostojski et al. 2011). The aim of this study was to analyse the variability of the two-hourly concentrations of total nitrogen and total phosphorus in the Stupia River during three measurement cycles.

\section{The characteristics of the pilot catchment}

The analysis of the variability of total nitrogen and total phosphorus concentrations was carried out in the Stupia catchment. The Słupia (Fig. 1) is a coastal river that flows into the Baltic Sea after crossing the Ustka urban area in Northern Poland.

The catchment area is about $1623 \mathrm{~km}^{2}$, and the length of the main watercourse is $139 \mathrm{~km}$ (Hydrological Forecasting Office 2011). The river's source is located approximately $200 \mathrm{~m}$ above sea level in the Kashubian Lake District. The most important tributaries of the Shupia River are the Boruja, Bytowa, Jutrzenka, Kamienica, Brodek, Graniczna, Warblewska Struga, Skotawa, Kwacza, Głaźna, Kamieniec, and Gnilna. The width of the riverbed varies from $7 \mathrm{~m}$ upstream to $40 \mathrm{~m}$ at the mouth of the river, with the average flow at the mouth recorded as $15.5 \mathrm{~m}^{3} / \mathrm{s}$ and the average decrease as approximately $1.3 \%$. Krzynia and Konradowo water reservoirs are located on the Słupia. The Słupia River basin is predominantly used for agriculture (48\% of the area). Forests cover an area of $704 \mathrm{~km}^{2}$, which represents $43 \%$ of the whole catchment area (WIOŚ 2008). Into the Słupia flows point sources pollution as well as diffuse source pollution - this is caused mainly due to the nature of the agro-forestry in the catchment area and its location on the route of the watercourse of the cities of Słupsk and Ustka. The main point source pollution comes from:

- the mechanical and biological wastewater treatment plant in Słupsk (22 $\left.700 \mathrm{~m}^{3} / \mathrm{d}\right)$;

- the mechanical and biological wastewater treatment plant in Ustka $\left(6250 \mathrm{~m}^{3} / \mathrm{d}\right)$;

- the mechanical and biological wastewater treatment plant in Sulęczyno $\left(134 \mathrm{~m}^{3} / \mathrm{d}\right)$;

- the streams and rivers flowing into the Stupia, which carry waters affected by agriculture and waste from a fish farm and some amounts of municipal waste;

- villages lying in the river's basin, which do not have proper wastewater and sewage management.

Diffuse pollution is mainly runoff from fields and agricultural holdings, as well as from fish farms. The water catchment areas of the Słupia River were classified as having a middle level of human pressure in accordance with (Bogdanowicz 2004; Scholefield et al. 2005). In this classification the production of agricultural sources of pollution and the degree of water pollution were taken into account (Jarosiewicz, Dalszewska 2008).

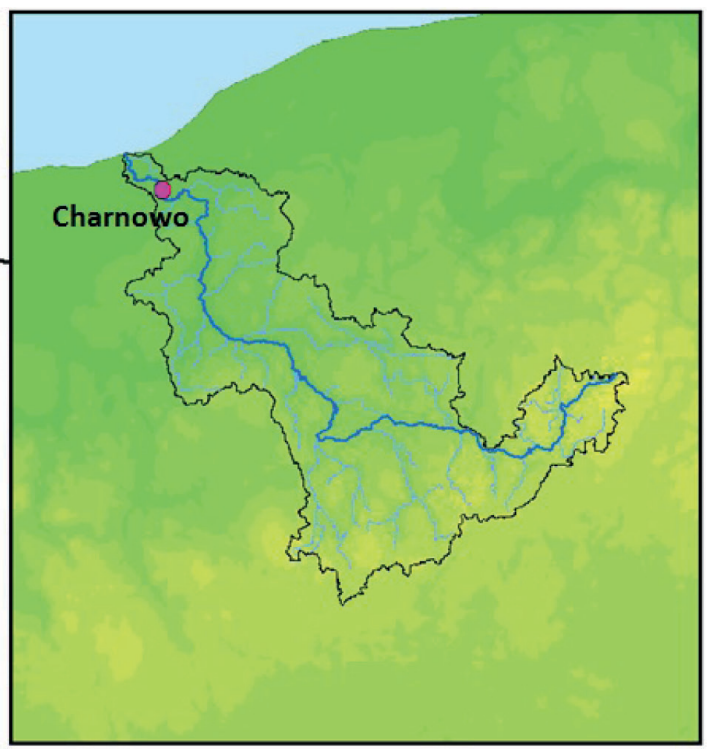

Fig. 1. The Słupia catchment area with Charnowo river profile indication (Hydrological Forecasting Office 2011) 
The study was conducted in the river profile (located in village of Charnowo) at $12.14 \mathrm{~km}$ (designated as the river profile of the Uniform Surface Water Body (JCWP) according to the WFD (Directive 2000/60/EC), which is the last water gauge on the river course before it reaches the sea, and is beyond the influence of the backwater (Fig. 1). The selected Charnowo river profile is particularly interesting due to the fact that a semi-automatic device to collect water samples is located at this location. This river profile is also used by SEM to assess the status of water in the Słupia River.

\section{Materials and methods}

A series of measurements were performed every two hours for three days in each of the cycles (Fig. 2). Consequently, 36 results for the instantaneous measurements were obtained. The results of the single measurements conducted every 2 hours were compared with the calculated average daily amount of total nitrogen and total phosphorus concentrations. The terms of measurements have been selected in order to:

- capture a moment in which plants were absent on cultivated fields, fertilizers were not applied and autumn rains began (15.11.2013-16.11.2013) - cycle I;

- capture a moment immediately after the spring thaw (27.02.2014-01.03.2014) - cycle II;

- capture a moment of intense plant vegetation and use of fertilizers (19.06.2014-21.06.2014) - cycle III.

On the basis of separate studies it can be concluded that in the first two cases significant surface runoff from cultivated fields can be expected, while in the third case the runoff should be limited by crops (Gębala 2015).

Water sampling was made in accordance with the current ISO standards ISO 5667-3:2005 and ISO 5667-5:2003.

The imprecision of instruments used, as well as the human factor, influence the error of measurement results (Burnos 2010). The acceptable error is the maximum measurement error which does not significantly change the meaning of the obtained value. When presenting a measurement, extra information should be included concerning the quality of the obtained measurement, resulting from its accuracy, that is the standard measurement uncertainty. Measurement uncertainty is defined as »a parameter, associated with a result of a measurement that characterises the dispersion of the values that could be reasonably attributed to the measured value« (ISO 1993).

The sources of that uncertainty are, inter alia:

- incomplete definition of a measured value;

- incomplete knowledge of the environment impact on a measured value as well as imperfect environmental conditions;

- errors in reading an instrument;

- accuracy class of measuring instruments;

- imperfection of measurement method etc.

Confidence level $\alpha$ can be assigned to the uncertainty. Monitoring measurements in Poland are affected by widened measurement uncertainty, declared to be $20 \%$ for total nitrogen and $10.5 \%$ for total phosphorus, with a confidence interval of $\alpha=0,05$ and an expansion coefficient equal to 2 , as in Table 1 .

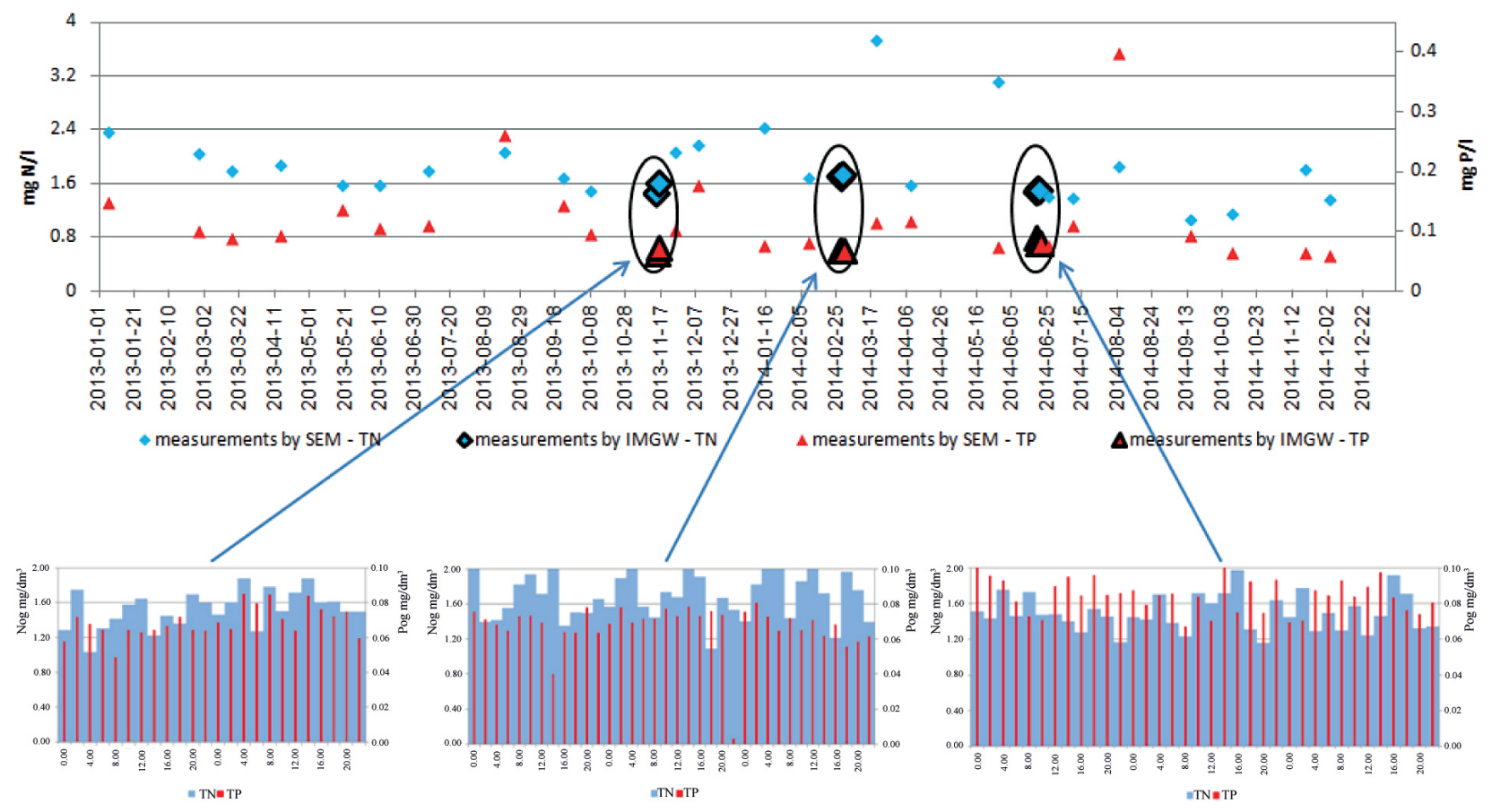

Fig. 2. The results of field research against the background of SEM measurements (source: own study) 
Table 1. Measurement range value, markings, and widened uncertainty borders for total nitrogen and total phosphorus, conducted by SEM (Regional Inspectorate for Environmental Protection 2009)

\begin{tabular}{|c|c|c|c|c|c|c|}
\hline Lp. & Measurement range & Measured object & Polish Norm & Unit & Measuring range & $\begin{array}{c}\text { Uncertainty [\%] } \\
(\alpha=0,05), k=2\end{array}$ \\
\hline 1 & total nitrogen & water, sewage & PB-35.00.00.00 4:10.03.2011 spectrophotometer & $\mathrm{mgN} / 1$ & $0.26-96$ & 20 \\
\hline 2 & total phosphorus & water, sewage & PN-EN ISO 6878:2006/Ap1i2:2010 spectrophotometer & $\mathrm{mgP} / 1$ & $0,018-25$ & 10,5 \\
\hline
\end{tabular}

Methods of calculating total nitrogen and total phosphorus concentrations in waters are defined by norms (Dz. U. z 2001 r. Nr 115, poz. 1229), shown in Table 1. For total nitrogen the measurement range, according to an accepted method, is between 0.26 to $96 \mathrm{mg} \mathrm{N} / 1$. For total phosphorus, though, the range is 0.018 to $25 \mathrm{mg} \mathrm{P} / 1$.

For the three series of measurements the following mathematical statistics were used (Niedokos 1990; Stoer, Bulirsch 1991):

- the minimum, meaning the minimum value of the observed instantaneous measurement on a particular day and cycle;

- the maximum, meaning the maximum value of the observed instantaneous measurement on a particular day and cycle;

- mean daily concentration of total nitrogen and total phosphorus;

- the quantity of dispersion as a percentage of value deviations between the minimum and the maximum value to the daily mean from a particular day:

$$
R=\frac{X_{\max }-X_{\min }}{\bar{X}}
$$

where: $R$ - data dispersion within the day; $X_{\max }$ - maximum value of the measurement during the day; $X_{\min }-$ minimum value of the measurement during the day; $\bar{X}$ - mean value of the measurement during the day.

Data dispersion shows, in a simple manner, the behavior of nutrients in the river over time. At the same time, from the perspective of the calibration of nitrogen and phosphorus by physical models it makes it possible to correctly assess the fit of the modeling results to observation data (Tappin et al. 2011).

The results for cycles I, II and III are presented in Tables 2,3 , and 4 respectively.

\section{Results}

Based on the conducted measurements, the instantaneous values of total nitrogen and total phosphorus concentration were obtained. The daily arithmetic mean was calculated from 12 measurements. As a result, three daily means of total nitrogen and total phosphorus concentration were obtained (only two in cycle I). For the purpose of the following examination it was assumed that the beginning of the day in cycles I, II and III was at 00:00, and the end at 22:00. The results of measurements for the cycles I, II and III are presented in Fig. 3, 4 and 5 respectively.

The result obtained for total phosphorus concentration in cycle II, on day 2 at 22:00 (Fig. 3) is noteworthy. Such an extreme observation result may imply error at the measurement stage or during the marking of samples in the laboratory. It should be noted that because of the inaccuracy of instruments and measuring methods, the imperfections of human labour and the uncontrolled variability of environmental conditions, the result of a measurement is always different from the actual measured value and constitutes a more or less accurate approximation. Even in the case of short series of measurements, data outliers are inevitable. A characteristic feature of outlier data is that it can significantly affect the results of any statistical analysis (Ostojski 2012). Therefore, when using such data, for example to calibrate a mathematical model, it is necessary to reduce the impact of the outliers by eliminating them from a data set or to give them the appropriate weighting by using, inter alia, robust statistics. Long-term analysis of data sets has shown that, typically, about $10 \%$ of the data has at least a suspect character (Zaleski 2004). Other sources say that the amount of $5-10 \%$ of erroneous data is the rule rather than the exception (Bickel 1976). Therefore, for further analysis of the two-hourly variability of total phosphorus concentration, the result of the total phosphorus concentration in cycle II, on day 2 at 22:00, was not taken into account (Pottkämper 2010).

A large dispersion of two-hourly concentrations of total nitrogen and total phosphorus within the studied days was observed in each of the cycles. In cycle I the average dispersion of measurement results for the analysed days was $44 \%$ for total nitrogen and $36 \%$ for total phosphorus (Table 2). In cycle II the average dispersion of measurement results for the analysed days was $62 \%$ for total nitrogen and $68 \%$ for total phosphorus (Table 3 ). In cycle III the average dispersion of measurement results for the analysed days was $46 \%$ for total nitrogen and $48 \%$ for total phosphorus (Table 4). These are significant differences in the measurement results of total nitrogen and total phosphorus concentrations carried out for the particular hours of three consecutive days. The ratio between deviation 
Table 2. Statistical parameters for the measurements conducted in cycle I (source: own study)

\begin{tabular}{|c|c|c|c|c|c|}
\hline Cycle I & $\begin{array}{c}\text { Uncertainty } \\
{[\%](k=2)}\end{array}$ & $\begin{array}{c}\text { Mean } \\
{[\mathrm{mg} / 1]}\end{array}$ & $\begin{array}{c}\text { Minimum } \\
{[\mathrm{mg} / 1]}\end{array}$ & $\begin{array}{c}\text { Maximum } \\
{[\mathrm{mg} / \mathrm{l}]}\end{array}$ & $\begin{array}{c}\text { Dispersion } \\
{[\%]}\end{array}$ \\
\hline \multicolumn{7}{|c|}{ Day 1} \\
\hline Total nitrogen & 12,37 & 1,45 & 1,04 & 1,75 & 49 \\
Total phosphorus & 0,36 & 0,06 & 0,05 & 0,07 & 36 \\
\hline \multicolumn{7}{|c|}{ Day 2 } \\
\hline Total nitrogen & 10,5 & 1,61 & 1,27 & 1,88 & 38 \\
Total phosphorus & 0,5 & 0,07 & 0,06 & 0,09 & 35 \\
\hline
\end{tabular}

Table 3. Statistical parameters for the measurements conducted in cycle II (source: own study)

\begin{tabular}{|c|c|c|c|c|c|}
\hline Cycle II & $\begin{array}{l}\text { Uncertainty } \\
{[\%](k=2)}\end{array}$ & $\begin{array}{l}\text { Mean } \\
{[\mathrm{mg} / \mathrm{l}]}\end{array}$ & $\begin{array}{c}\text { Minimum } \\
{[\mathrm{mg} / \mathrm{l}]}\end{array}$ & $\begin{array}{c}\text { Maximum } \\
{[\mathrm{mg} / \mathrm{l}]}\end{array}$ & $\begin{array}{c}\text { Dispersion } \\
{[\%]}\end{array}$ \\
\hline \multicolumn{6}{|c|}{ Day 1} \\
\hline Total nitrogen & 20 & 1,71 & 1,35 & 2,48 & 66 \\
\hline Total phosphorus & 0,6 & 0,07 & 0,04 & 0,08 & 57 \\
\hline \multicolumn{6}{|c|}{ Day 2} \\
\hline Total nitrogen & 16,4 & 1,69 & 1,09 & 2,17 & 64 \\
\hline Total phosphorus* & 1,2 & 0,07 & 0,07 & 0,08 & 13 \\
\hline \multicolumn{6}{|c|}{ Day 3} \\
\hline Total nitrogen & 18,44 & 1,74 & 1,21 & 2,21 & 57 \\
\hline Total phosphorus & 0,43 & 0,07 & 0,06 & 0,08 & 37 \\
\hline
\end{tabular}

* after removal from the measurement results at 22:00

Table 4. Statistical parameters for the measurements conducted in cycle III (source: own study)

\begin{tabular}{|c|c|c|c|c|c|}
\hline Cycle III & $\begin{array}{l}\text { Uncertainty } \\
{[\%](k=2)}\end{array}$ & $\begin{array}{l}\text { Mean } \\
{[\mathrm{mg} / \mathrm{l}]}\end{array}$ & $\begin{array}{l}\text { Minimum } \\
{[\mathrm{mg} / \mathrm{l}]}\end{array}$ & $\begin{array}{c}\text { Maximum } \\
{[\mathrm{mg} / \mathrm{l}]}\end{array}$ & $\begin{array}{c}\text { Dispersion } \\
{[\%]}\end{array}$ \\
\hline \multicolumn{6}{|c|}{ Day 1} \\
\hline Total nitrogen & 9,4 & 1,47 & 1,17 & 1,76 & 40 \\
\hline Total phosphorus & 0,8 & 0,09 & 0,07 & 0,13 & 61 \\
\hline \multicolumn{6}{|c|}{ Day 2} \\
\hline Total nitrogen & 13,8 & 1,53 & 1,16 & 1,97 & 53 \\
\hline Total phosphorus & 0,65 & 0,08 & 0,07 & 0,11 & 48 \\
\hline \multicolumn{6}{|c|}{ Day 3} \\
\hline Total nitrogen & 12,34 & 1,49 & 1,25 & 1,92 & 45 \\
\hline Total phosphorus & 0,51 & 0,08 & 0,07 & 0,1 & 34 \\
\hline
\end{tabular}

quantities to daily mean values for cycles I, II and III is shown in the Fig. 6, 7 and 8.

For total nitrogen in cycle I, day 1 , the deviation reached values from $-28 \%$ to $21 \%$, and on day 2 from $-21 \%$ to $17 \%$ (Fig. 5). In cycle II, day I (Fig. 6) the values varied from $-21 \%$ to $45 \%$, on day 2 from $-35 \%$ to $28 \%$ and on day 3 from $-30 \%$ to $27 \%$. For cycle III (Fig. 7), values for total nitrogen on day 1 ranged from $-21 \%$ to $4 \%$, on day 2 from $-24 \%$ to $29 \%$ and on day 3 from $-16 \%$ to $29 \%$.

The quantities of total phosphorus deviations from daily mean values for cycles I, II and III are presented in Figures $9,10,11$.

For total phosphorus in cycle I, day 1 , the deviation reached values from $-24 \%$ to $12 \%$, and on day 2 from $-19 \%$ to $16 \%$ (Fig. 9). In cycle II, day 1 (Fig. 10) the values varied from $-41 \%$ to $17 \%$, on day 2 from $-95 \%$ to $16 \%$, and on day 3 from $-17 \%$ to $20 \%$. For cycle III (Fig.
11), values for total nitrogen on day 1 ranged from $-21 \%$ to $40 \%$, on day 2 from $-19 \%$ to $29 \%$, and on day 3 from $-16 \%$ to $18 \%$.

From the point of view of the proper determination of total nitrogen loads and total phosphorus loads discharged into the sea, the analysis performed above shows how important the proper determination of daily average concentrations of total nitrogen and total phosphorus is. The use of instantaneous value as a daily average may carry a $40 \%$ burden of error in the case of total nitrogen and a $90 \%$ burden of error in the case of total phosphorus. This error will affect the estimation of the size of pollutant loads. It should be remembered that the determination of the load size also influences the proper determination of the river flow (which is not the subject of this analysis), as well as the size of the measurement error, which is studied in this article. 


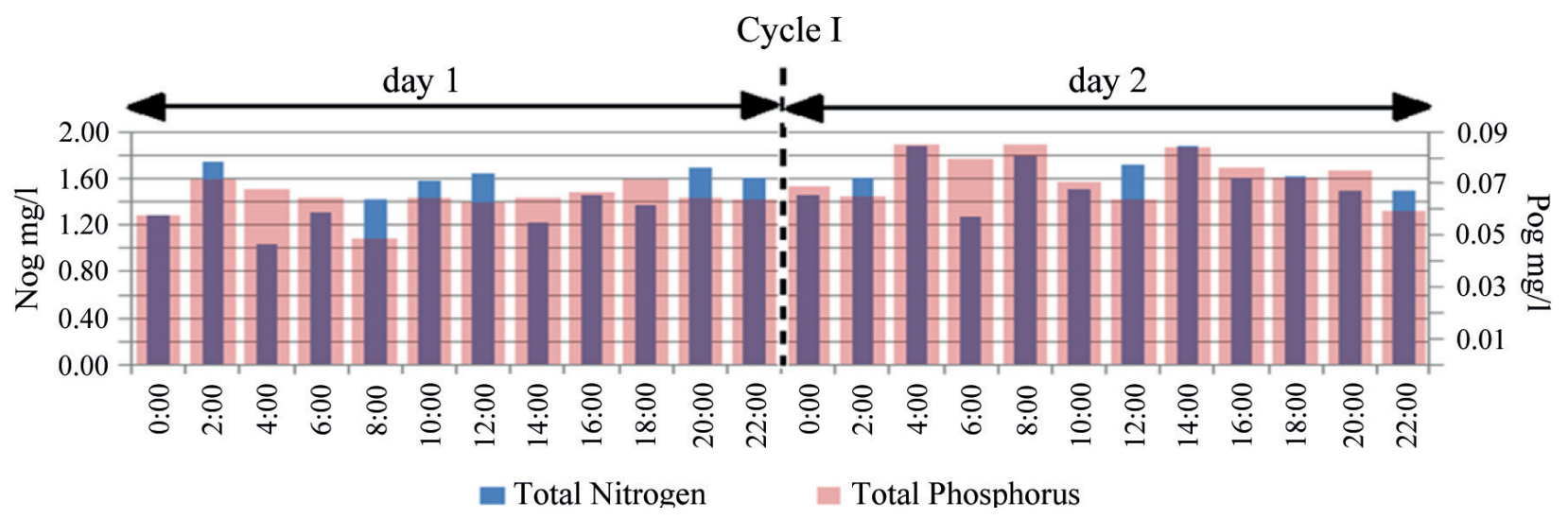

Fig. 3. Measurement results in cycle I (source: own study)

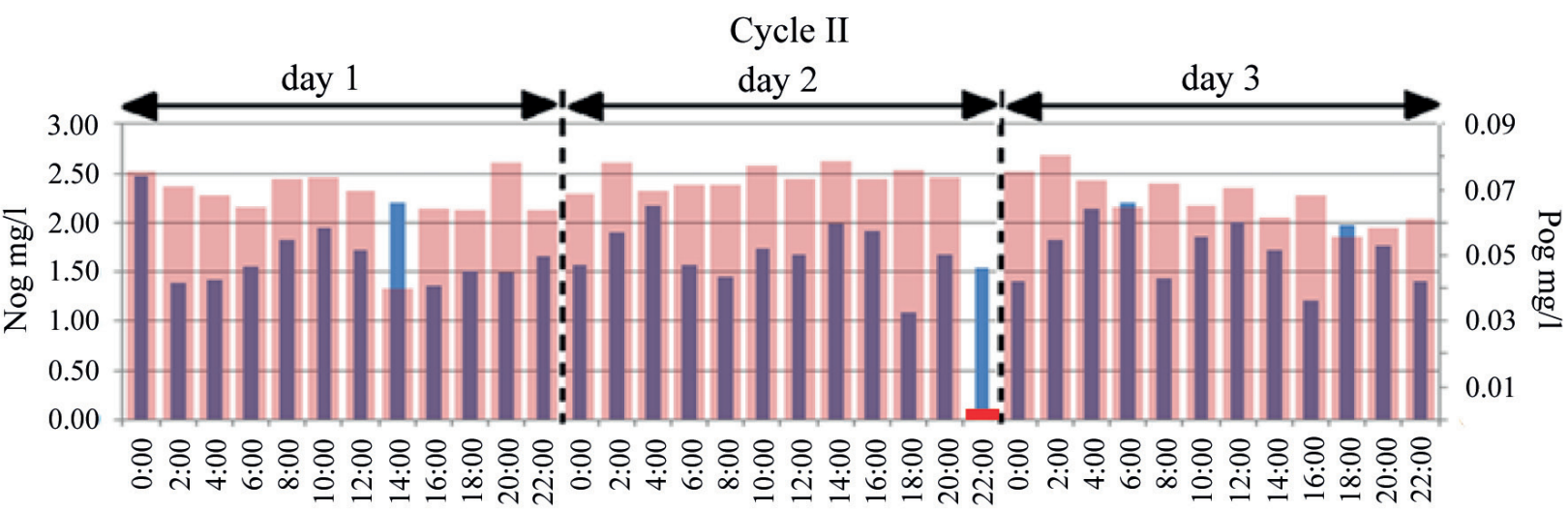

- Total Nitrogen $\quad$ Total Phosphorus

Fig. 4. Measurement results in cycle II (source: own study)

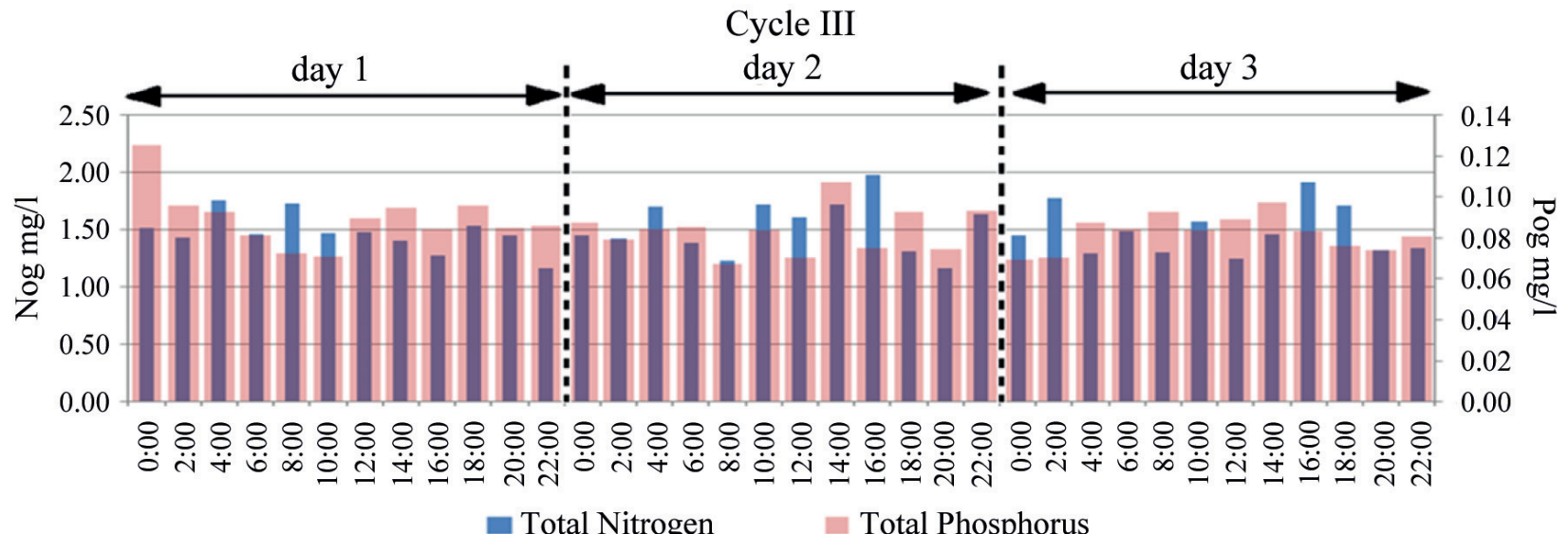

Fig. 5. Measurement results in cycle III (source: own study)

Figures 12-17 present the measurement results for cycles I, II and III. In addition, the results were covered with broadened uncertainty ranges of a single measurement defined by the Water Act (Dz. U. z 2001 r. Nr 115, poz. 1229). Dispersion intervals were marked separately for each cycle.

The analysis of Fig. 12, 14 and 16 shows that the dispersion range in cycles I and II for total nitrogen is in none of the cases included in the field of measurement uncertainty by SEM. Indeed, only in the third cycle is there one such a case (Table 5). In cycle I, day 1 , it can be observed for total nitrogen concentration that in two cases the standard deviation is within the range of measurement uncertainty by SEM, and on day 2 eight such cases can be observed (Table 5).

As far as cycle II is concerned, there are five cases noted on days 2 and 3 combined (Table 5). It follows that the maximum value of a single measurement on a given day has a decisive influence on the size of the dispersion range. The greatest dispersion of total nitrogen values was observed in February. 
Cykle I

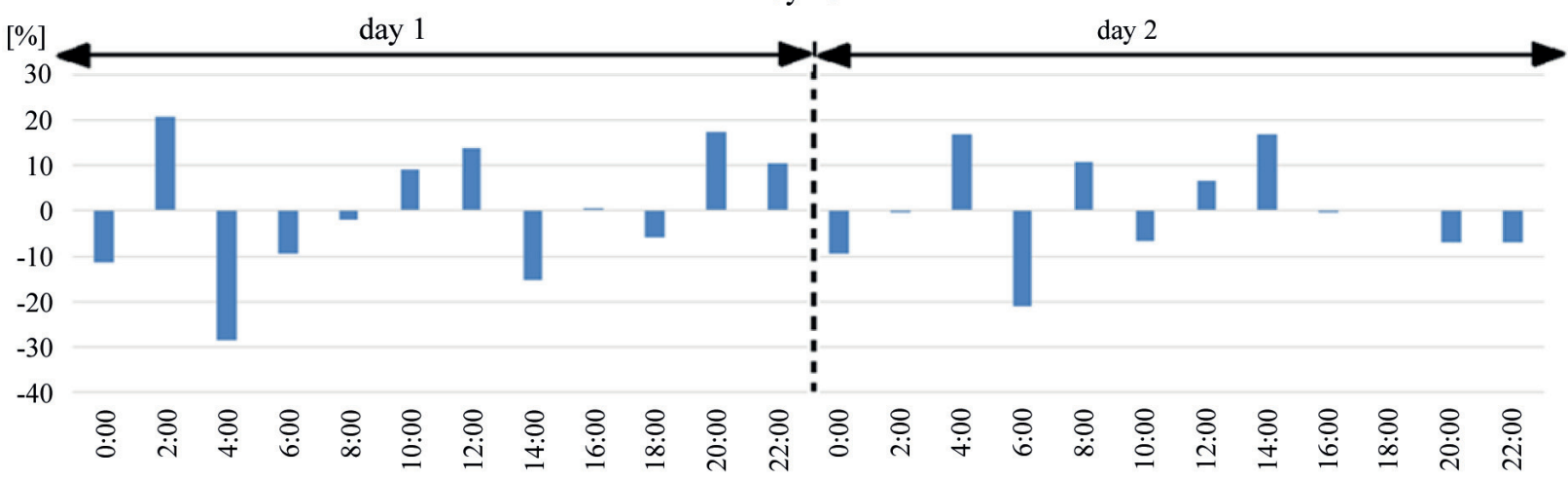

Fig. 6. Deviation of total nitrogen measurements from daily mean values in cycle I (source: own study)

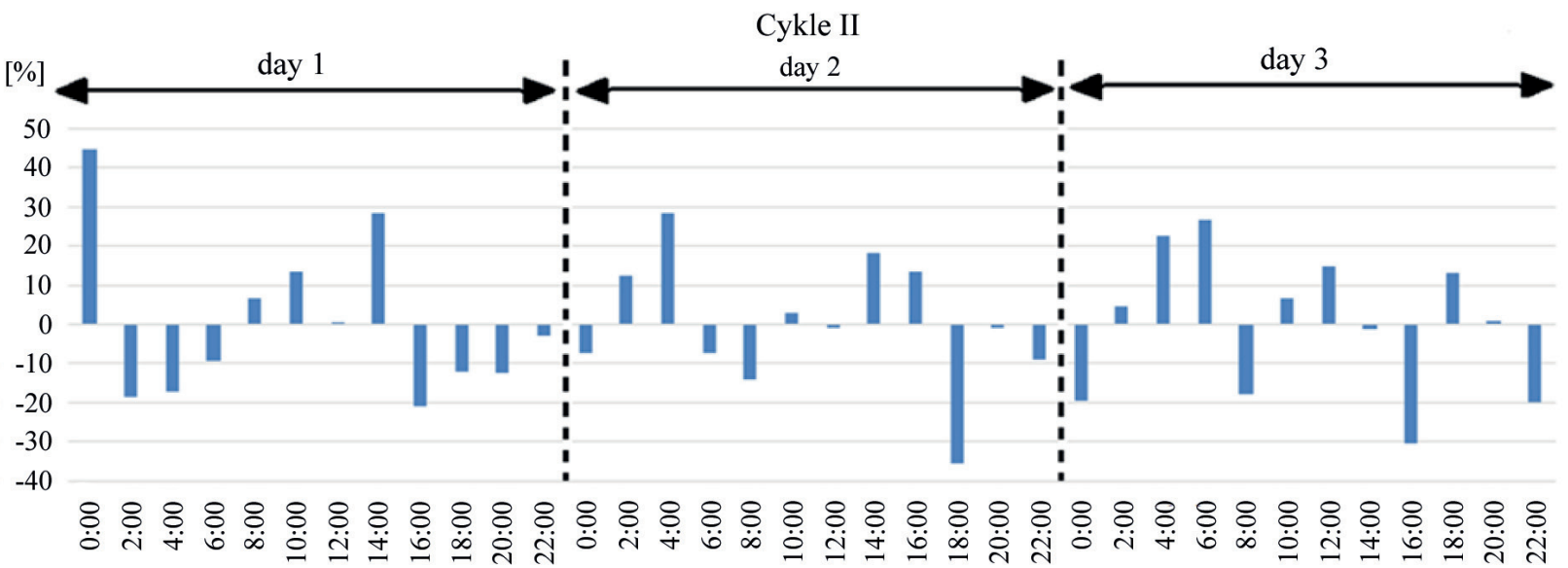

Fig. 7. Deviation of total nitrogen measurements from daily mean values in cycle II (source: own study)

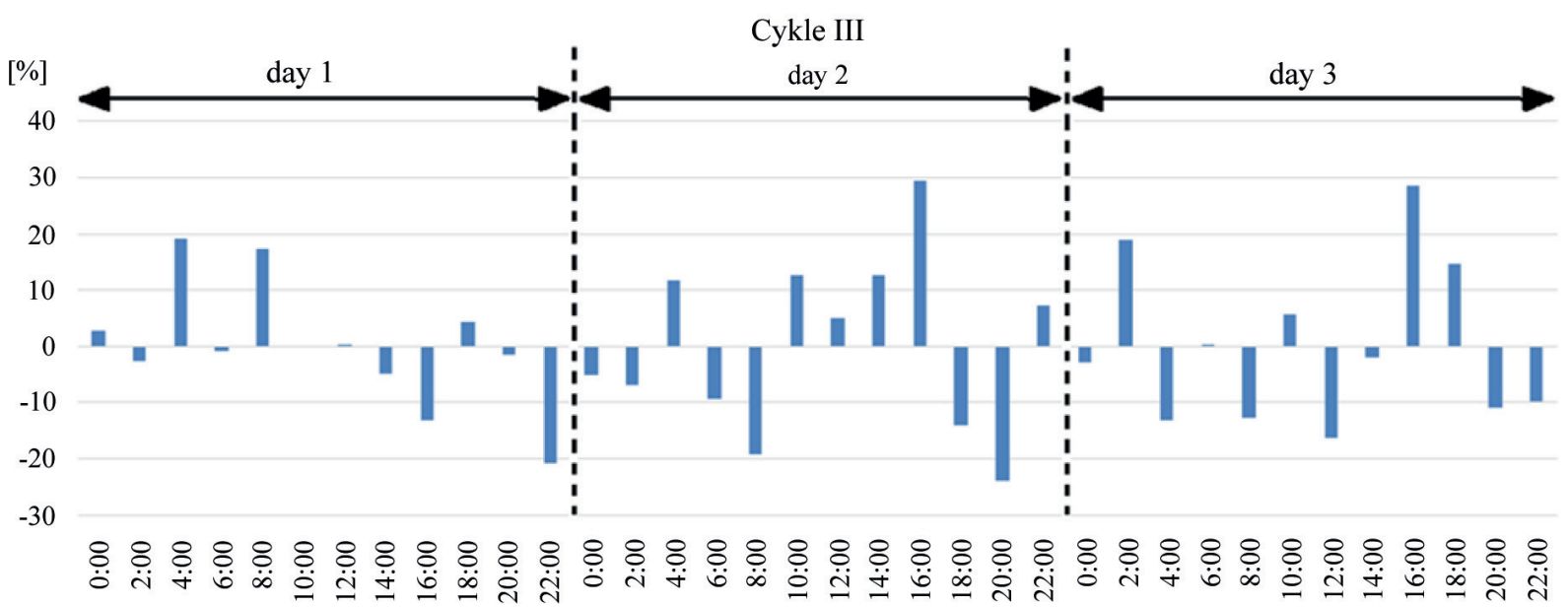

Fig. 8. Deviation of total nitrogen measurements from daily mean values in cycle III (source: own study)

The situation is similar in the case of total phosphorus concentrations. The analysis of Fig. 13, 15 and 17 (Table 6) shows that not once in cycles I-III is the dispersion range within the range of measurement uncertainty determined by SEM. However, in the case of the standard deviation on day I of cycle I, there are four cases when it is within the range of uncertainty determined by SEM. Similarly to total nitrogen concentration analysis, the maximum value of a single measurement on a given day has a decisive influence on the size of the dispersion range. The similarity to nitrogen was also observed for the period of the largest dispersion in cycle II (February).

\section{Summary and conclusions}

At the analysed river profile in cycles II and III the variability of total phosphorus concentration was a few times higher than the variability of total nitrogen concentration. This probably results from the characteristics of the source pollutants. The main sources of phosphorus in waters are 


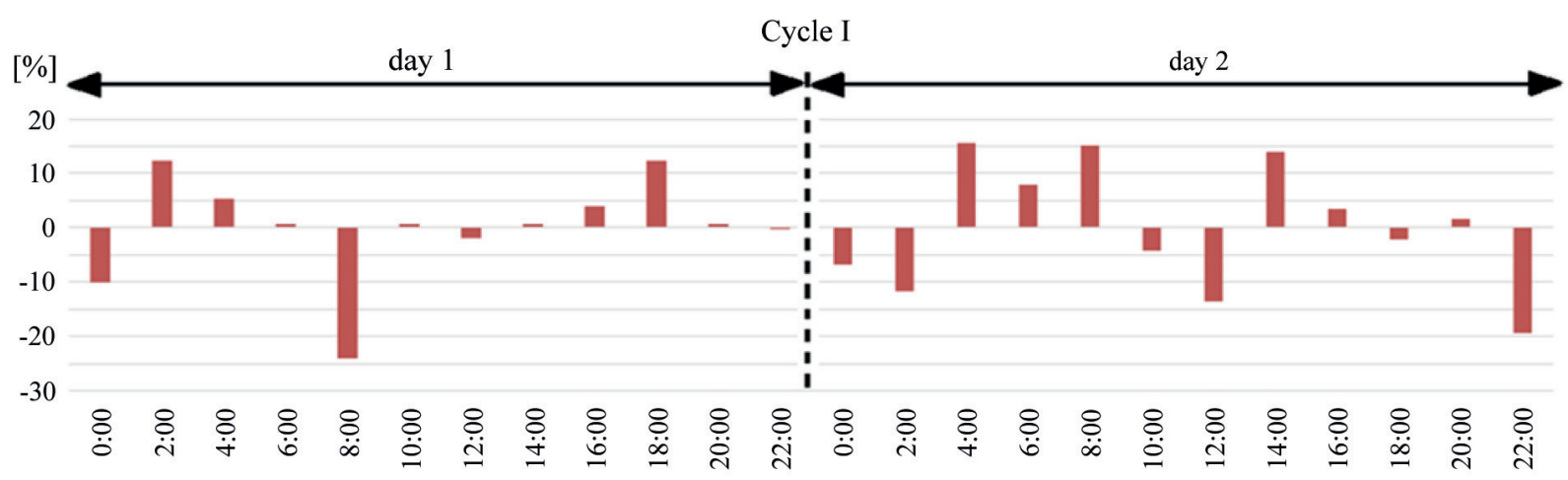

Fig. 9. Deviation of total phosphorus measurements from daily mean in cycle I (source: own study)

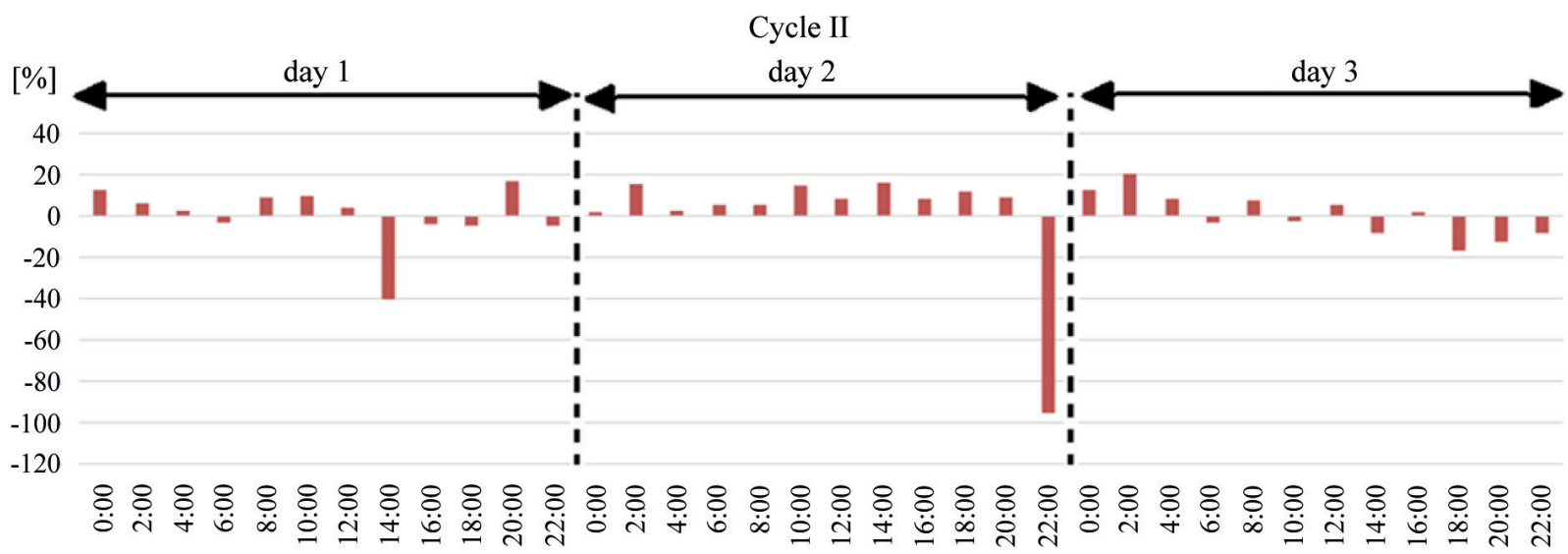

Fig. 10. Deviation of total phosphorus measurements from daily mean in cycle II (source: own study)

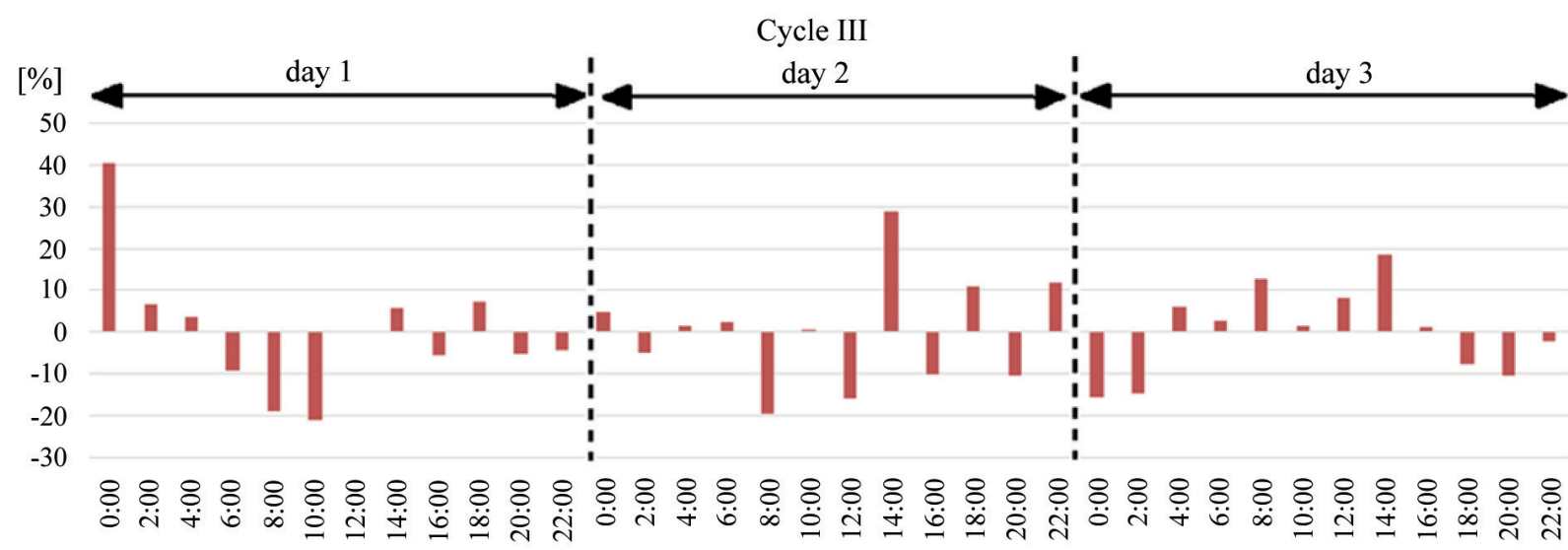

Fig. 11. Deviation of total phosphorus measurements from daily mean in cycle III (source: own study)

point discharges from waste water plants, as well as instantaneous discharge from untreated sewage. However, the main source of nitrogen in waters is agriculture, where leaching of total nitrogen to surface waters depends on meteorological conditions, the season of the year and the land use. The variability of total nitrogen at the analysed river profile was at a very similar level in each one of the three cycles considered (Table 7). No significant seasonal effect or the influence of the plant growing season on total nitrogen dispersion was observed.

A similar situation appears when analysing the dispersion of total phosphorus results. In all the analysed cycles, the dispersion of total phosphorus was at a similar level, and only in cycle III was it higher, reaching 61\% (Table 7). Nevertheless, the analysis of all three measurement cycles shows that the dispersion of phosphorus remained at a similar level to the dispersion of nitrogen.

The analysis of daily dispersion of total nitrogen and total phosphorus shows that using the instantaneous measurement of total nitrogen or total phosphorus as a daily mean value has a burden of error exceeding $60 \%$. In cases where instantaneous measurement values are replaced by monthly mean values, the error might be bigger.

The measurements carried out showed that the expanded uncertainty does not provide full knowledge of the measured values and the dynamics of changes in selected elements 


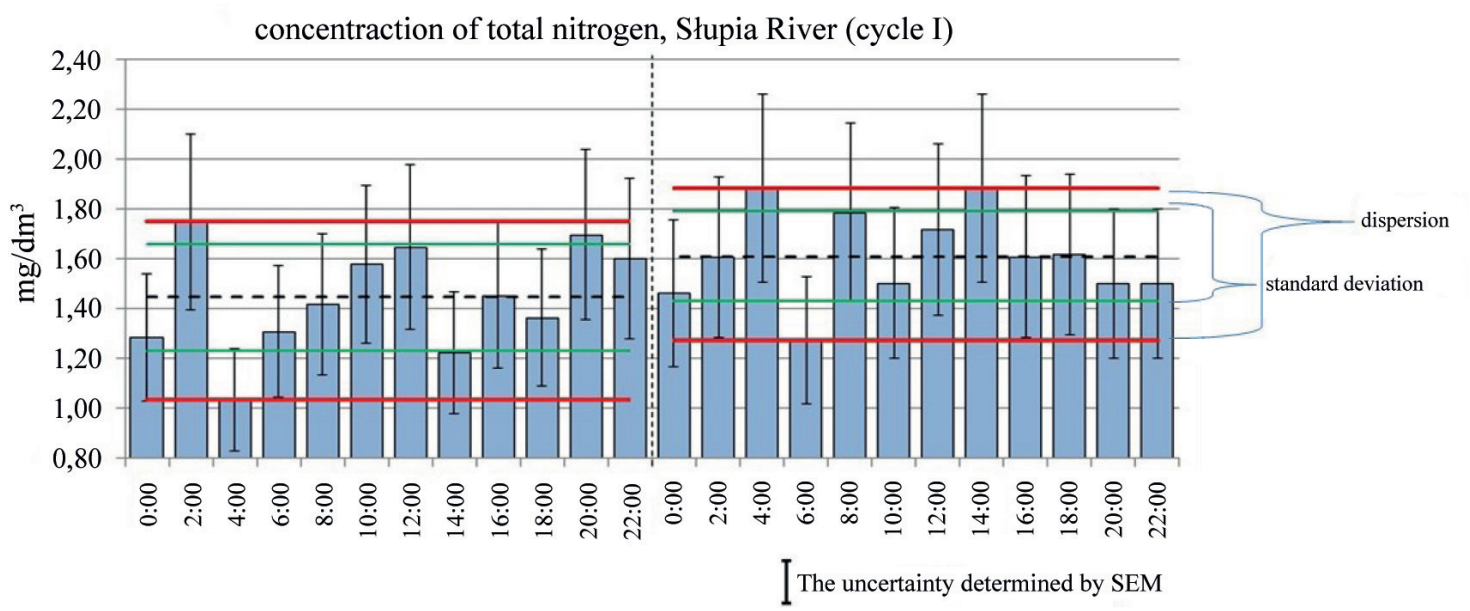

Fig. 12. Dispersion and broadened uncertainty of total nitrogen concentration in cycle I (source: own study)

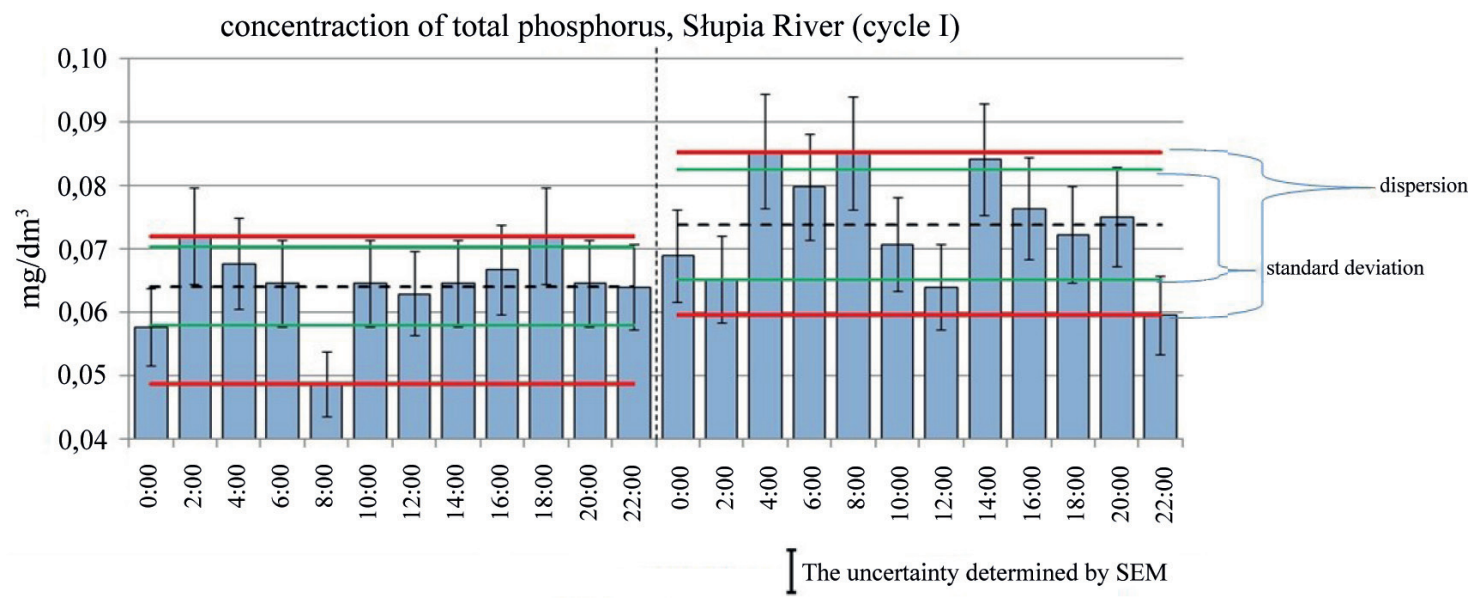

Fig. 13. Dispersion and broadened uncertainty of total phosphorus concentration in cycle I (source: own study)

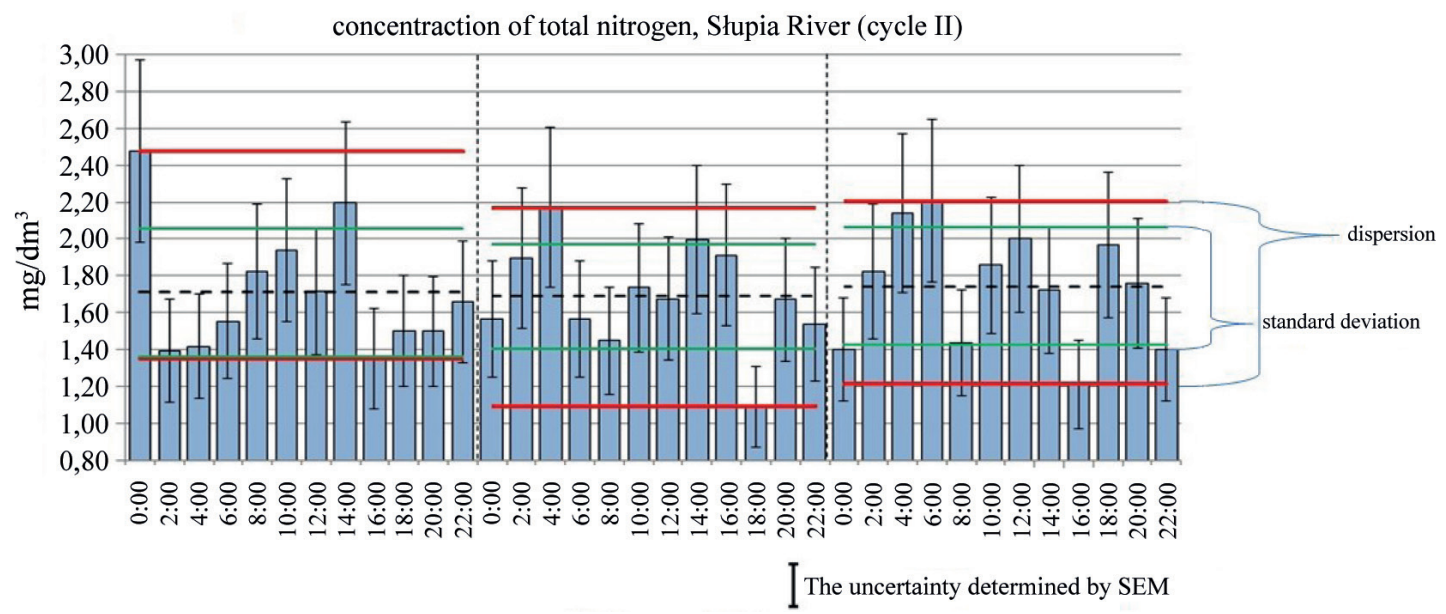

Fig. 14. Dispersion and broadened uncertainty of total nitrogen concentration in cycle II (source: own study)

within surface waters. The values of the expanded uncertainty in all three series and in all analysed days are in the ranges given by SEM (Tables 2, 3 and 4). This is particularly important from the point of view of mathematical models that exhibit high sensitivity to the quantity and quality of input data. This applies especially to phosphorus, which creates a big problem during model calibration process.
The analysed measurement cycles show that there is no possibility of establishing a "representative hour" of sampling. For example, the value of total nitrogen concentration taken at 8:00 in cycle I on day 1 differs significantly from the total nitrogen concentration value taken at the same time on day 2 . 


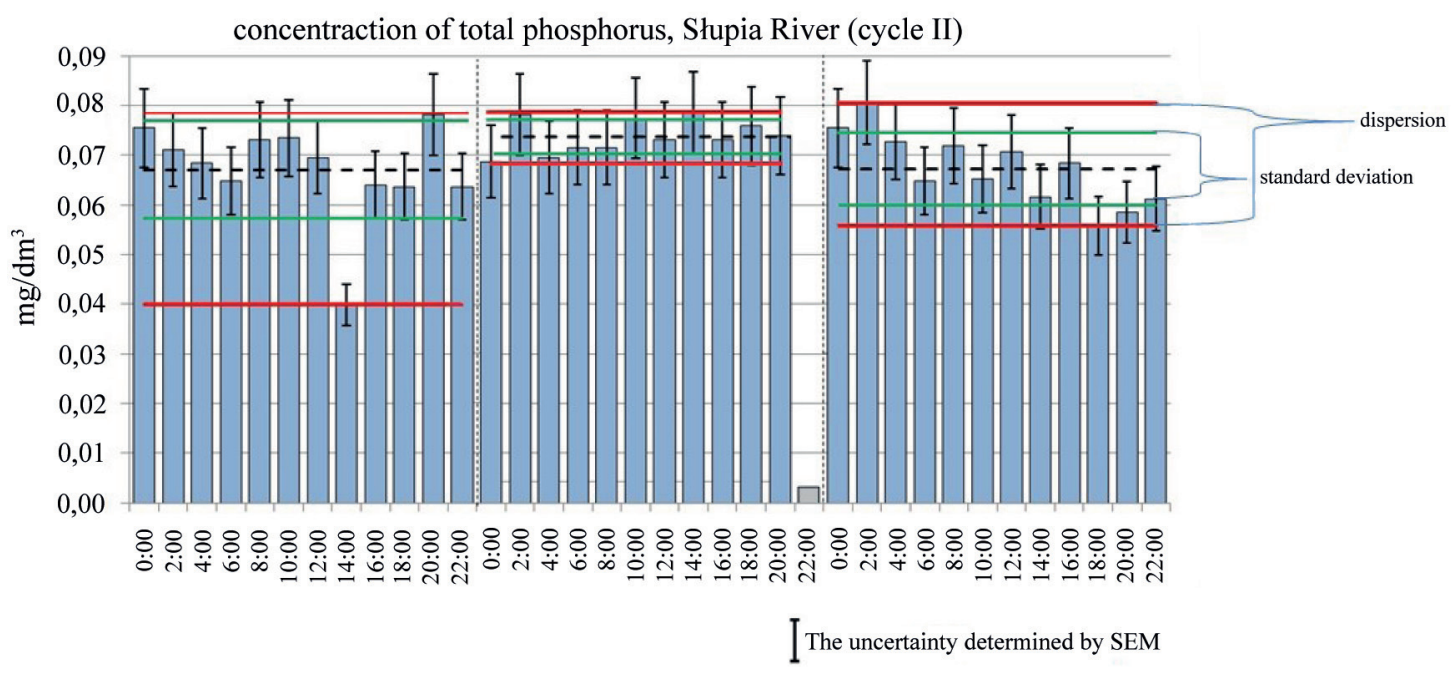

Fig. 15. Dispersion and broadened uncertainty of total phosphorus concentration in cycle II (source: own study)

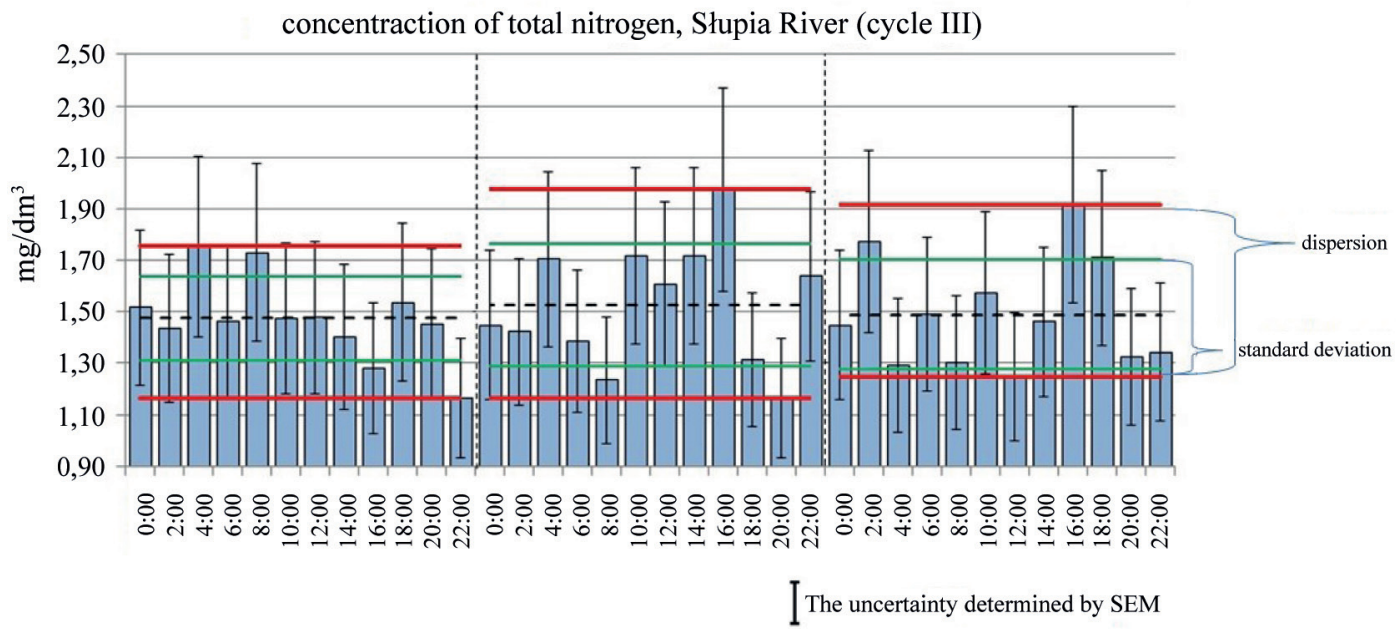

Fig. 16. Dispersion and broadened uncertainty of total nitrogen concentration in cycle III (source: own study)

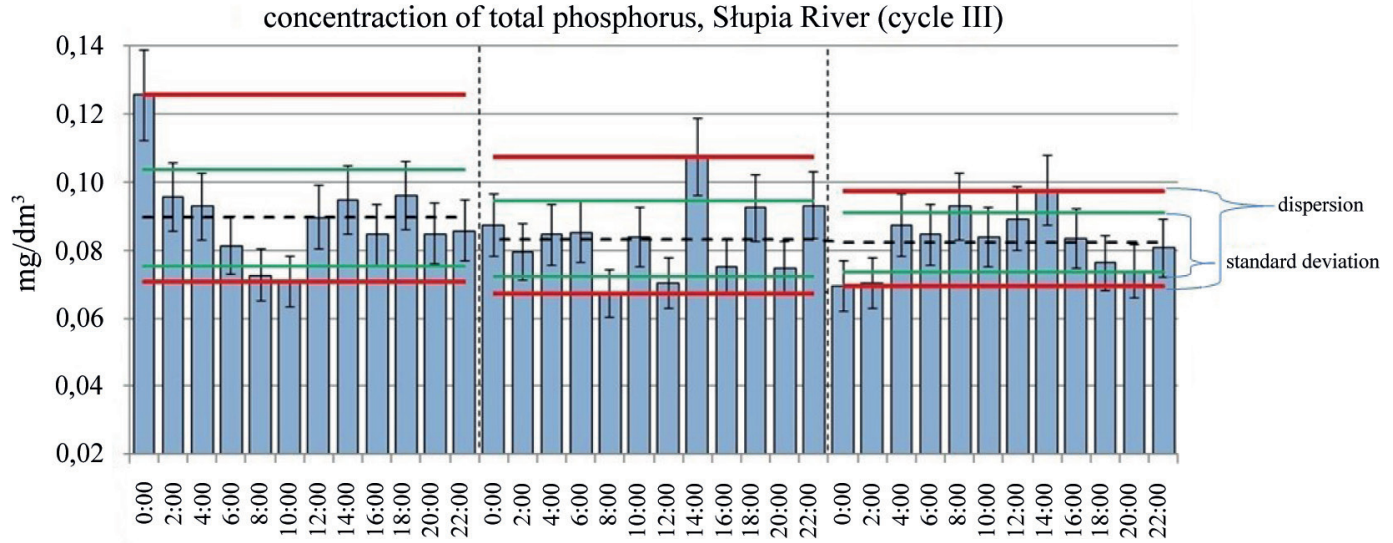

The uncertainty determined by SEM

Fig. 17. Dispersion and broadened uncertainty of total phosphorus concentration in cycle III (source: own study)

The knowledge of hourly deviations of pollutant concentrations in surface waters has a special meaning as far as total phosphorus calibration is concerned. Due to phosphorus having a high variability through time, it is hard to calibrate. In addition, it should be noted that the analysed
Shupia catchment constitutes little acreage and there are no agglomerations or large farms. It can be anticipated that in larger and more urbanised catchments, the dispersion values for total phosphorus will be higher. From the point of view of mathematical models, which are the basis for 
Table 5. Number of ranges of standard deviation and dispersion including the ranges of uncertainty determined by SEM for instantaneous measurements of total nitrogen concentrations (source: own study)

\begin{tabular}{|c|c|c|c|c|c|}
\hline & & \multicolumn{4}{|c|}{ Number of measurements } \\
\hline & & a) star & iation & & \\
\hline & & \multicolumn{4}{|c|}{ included in measurement error range } \\
\hline & & Yes & No & Yes & No \\
\hline \multirow{2}{*}{ Cycle I } & day 1 & 2 & 10 & 0 & 12 \\
\hline & day 2 & 8 & 4 & 0 & 12 \\
\hline \multirow{3}{*}{ Cycle II } & day 1 & 0 & 12 & 0 & 12 \\
\hline & day 2 & 3 & 9 & 0 & 12 \\
\hline & day 3 & 2 & 10 & 0 & 12 \\
\hline \multirow{3}{*}{ Cycle III } & day 1 & 8 & 4 & 1 & 11 \\
\hline & day 2 & 1 & 11 & 0 & 12 \\
\hline & day 3 & 4 & 8 & 0 & 12 \\
\hline
\end{tabular}

Table 6. Number of ranges of standard deviation and dispersion containing the ranges of uncertainty determined by SEM for instantaneous measurements of total phosphorus concentrations (source: own study)

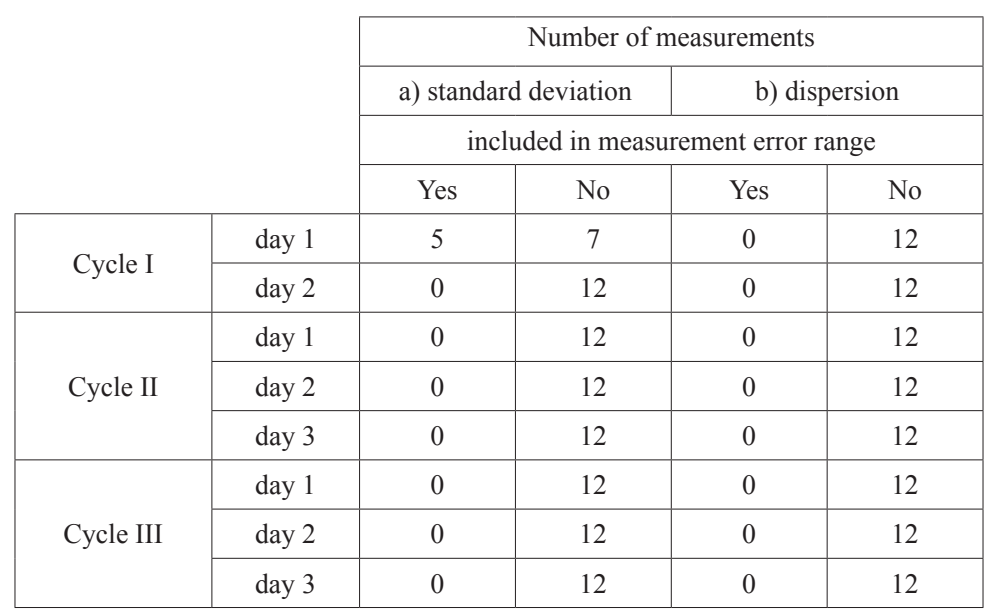

Table 7. Total nitrogen and total phosphorus daily variability within the months of the study (source: own study)

\begin{tabular}{|c|c|c|}
\hline \multirow{2}{*}{ Survey cycle } & \multicolumn{2}{|c|}{ Range of daily measurements dispersion } \\
\cline { 2 - 3 } & Total nitrogen & Total phosphorus \\
\hline cycle I & $38-49 \%$ & $35-36 \%$ \\
\hline cycle II & $57-66 \%$ & $13-57 \%$ \\
\hline cycle III & $40-45 \%$ & $34-61 \%$ \\
\hline
\end{tabular}

anticipating environmental changes, the high frequency of monitoring data is the basis for correctly defining those changes based on simulated data. Data gathered from field studies, described in this article, clearly indicate that the adopted extended uncertainty is too little, and in order to estimate it precisely, hourly variability in surface waters should be taken into consideration.

It is necessary to conduct further field studies in order to mark the parameters of total nitrogen and total phosphorus fluctuation within a period of one month, and then a period of one year, which should allow for the definition of real values of standard deviation of daily mean and monthly mean values. Research on this scale, followed by analysis, should be conducted for instantaneous water flow rate. Only then will it be possible to accurately estimate the quantities of total nitrogen and total phosphorus flowing through the analysed river profile.

\section{Bibliography}

Bickel P., 1976, Another look at robustness. A review of reviews and some new developments [with discussion and reply], Scandinavian Journal of Statistics, 3 (4), 145-168

Burnos P., 2010, Analysis of errors and uncertainty of measurement (in Polish), AGH University, Cracow, http://www.kmet. 
agh.edu.pl/wp-content/uploads/dyd_eit/cw_02_teoria.pdf (data access 01.04.2016), 16 pp.

Bogdanowicz R., 2004, Hydrological factors influencing transport of selected nitrogen and phosphorus compounds from the Odra River, the Vistula River and Polish coastal rivers to the Baltic Sea (in Polish), Wydawnictwo Uniwersytetu Gdańskiego, Gdańsk, 159 pp.

Caffrey J., Chapin T., Jannasch H., Haskins J., 2007, High nutrient pulses, tidal mixing and biological response in a small California estuary: Variability in nutrient concentrations from decadal to hourly time scales, Estuarine, Coastal and Shelf Science, 71 (3-4), 368-380, DOI: 10.1016/j.ecss.2006.08.015

Directive 2000/60/EC of the European Parliament and of the Council establishing a framework for the Community action in the field of water policy

Dz. U. z 2001 r. Nr 115, poz. 1229 (in Polish), Polish Law Act

Dz. U. z 2011 r. Nr 257, poz. 1545, Regulation of the Minister of the Environment on the classification of surface water bodies and environmental quality standards for priority substances (in Polish), Polish Law Act

Dz. U. z 2011 r. Nr 258, poz. 1550, Regulation of the Minister of Environment on the forms and manner of monitoring of surface water bodies and groundwater bodies (in Polish), Polish Law Act

Gębala J., Orlińska-Woźniak P., Wilk P., 2013, Surface water pollution from agricultural sources with nitrogen compounds in Poland - selected problems of water quality assessment (in Polish), Gospodarka Wodna, 11, 424-430

Gębala J., 2015, The method of assessing the impact of agricultural anthropogenic pressure on the quality of surface water (in Polish), dissertation, supervisor M. Ostojski, IMGW-PIB, Warszawa

Hydrological Forecasting Office, Map of hydrographic division of Poland, Operating materials from the years 2005-2011, IMGW-PIB, Warszawa

ISO, 1993, Guide to the Expression of Uncertainty in Measurement, The International Organization for Standardization ISO

Jarosiewicz A., Dalszewska K., 2008, Biogens dynamics in the Stupia River - self-purification ability of the river (in Polish), Słupskie Prace Biologiczne, 5, 63-73
Niedokos E., 1990, The use of probability and mathematical statistics (in Polish), PWN, Warszawa

Ostojski M., 2008, The Water Framework Directive of the European Union - the status of implementation in Poland (in Polish), IMGW, Warszawa, 112 pp.

Ostojski M., 2012, Process modeling discharge of nutrients into the Baltic Sea (in Polish), PWN, Warszawa, 256 pp.

Ostojski M., Orlińska P., Wilk P., 2011, The importance of scientific research to protect the aquatic environment of the Baltic Sea (in Polish), [in:] Stan środowiska polskiej strefy przybrzeżnej Bałtyku w latach 1986-2005, M. Miętus, M. Sztobryn (eds.), IMGW-PIB, Warszawa, 10-18

Pottkämper T., 2010, Evaluating perceived uncertainty using survey based dispersion measures, Master-Thesis, Maastricht University, 68 pp., http://arno.uvt.nl/show.cgi?fid=112916 (data access 10.05.2016)

Regional Inspectorate for Environmental Protection in Poznań, Delegation Zielona Góra, 2009, card research laboratory delegation in Gorzów Wielkopolski, http://www.zgora.pios.gov. pl/wp-content/uploads/2012/12/Karta-zakresu-lipiec-2013. pdf (data accessed 06.11.2015)

Scholefield D., Le Goff T., Braven J., Ebdon L., Long T., Butler M., 2005, Concerted diurnal patterns in riverine nutrient concentrations and physical conditions, Science of the Total Environment, 344 (1-3), 201-210, DOI: 10.1016/j.scitotenv.2005.02.014

Stoer J., Bulirsch R., 1991, Introduction to Numerical Analysis, $2^{\text {nd }}$ edition, Springer Verlag, $672 \mathrm{pp}$.

Tappin A.D., Millward G., Burton J., 2001, Estuarine and coastal water chemistry in land-ocean interaction in measuring and modelling fluxes from river basins to coastal seas, IWA Publishing, 241-279

WIOŚ, 2008, Report on the State of the Western Pomeranian environment in years 2006-2007 (in Polish), WIOŚ, Szczecin, $246 \mathrm{pp}$.

Zaleski J., 2004, Stochastic models and computer simulation. Application to water supply systems (in Polish), PWN, Warszawa, $455 \mathrm{pp}$. 